\title{
Impact Study of Machine Transplantation in Rice and its Socio-economic Comparison with Conventional Method in Cauvery Delta Region of Tamil Nadu, India
}

\author{
M. Nirmala Devi ${ }^{*}$, C. Harisudan ${ }^{2}$ and R. Arunachalam ${ }^{3}$ \\ ${ }^{1}$ Department of Agrl. Extension, Agrl. College and Research Institute, \\ Vazhavachanur, Thiruvannamalai District, India \\ ${ }^{2}$ Department of Agronomy, Regional Research Station, Vridhachalam, \\ Cuddalore, India \\ ${ }^{3}$ Department of Agrl. Extension), Dept. of Extension Education and Rural Sociology, \\ Tamil Nadu Agricultural University, Coimbatore, India \\ *Corresponding author
}

A B S T R A C T

\begin{tabular}{|c|}
\hline Keywords \\
\hline $\begin{array}{l}\text { Machine } \\
\text { transplanting, } \\
\text { labour saving, } \\
\text { Comparative } \\
\text { economics and Cost } \\
\text { of production }\end{array}$ \\
\hline Article Info \\
\hline $\begin{array}{l}\text { Accepted: } \\
18 \text { May } 2020 \\
\text { Available Online: } \\
10 \text { June } 2020\end{array}$ \\
\hline
\end{tabular}

Keywords

Machine

Comparative

economics and Cost

of production

Article Info

Accepted:

18 May 2020

10 June 2020
Adoption of Machine transplanting in rice helps to manage the drudgery in manual transplanting and also it is an ideal solution both in economic and environmental point of view. Hence, analysing the impact of machine transplanting in Cauvery delta districts was taken up during Kuruvai rice growing season. In Tamil Nadu, Thanjavur, Tiruvarur, Nagapattinam, Trichy, Ariyalur and Cuddalore are the Delta districts covered under Cauvery Delta Zone, in which Government of Tamil Nadu has implemented the Kuruvai Package for the farmers to boost up the production in Kuruvai cultivation during 2015. This impact study is pertaining to Cauvery Delta region under Cuddalore District. This study aims at to analysis the socio economic comparison in seedling production per acre, merits and demerits of machine transplanting in Cauvery delta zone. The focused research study revealed that majority of the farmers with the farming experience of 10 -30 years, cultivating major varieties viz., ASD 16, ADT 43 and Ponni reported the total cost of production in mat nursery method is much less than the conventional method and it saves 59 percentage in cost of production when compared to conventional method. Increased yield, reduced cost of cultivation, more area coverage, labour drudgery reduction, less effort in nursery maintenance, reduced seed cost, efficient labour management and timely planting are the major merits of machine transplanting.

\section{Introduction}

Rice (Oryza sativa) is the major crop of Tamil Nadu and the foremost staple food of its people. The crop occupies an extensive area of cultivation throughout the districts of the state. Rice occupies an area of $1.44 \mathrm{~m}$ ha in the state (Season and Crop Report, 2016-17). The traditional way of transplanting rice seedlings using labourers is highly manpower intensive, a laborious task and cost intensive too (Verma, 2010). 
The rice cultivation during peak season always faces the problem of labour scarcity which leads to late planting and skipping of season and in turn invites the problem of reduction in production. Adoption of Mechanical transplanting in rice helps in overcoming the drudgery in manual transplanting and also it is an ideal solution both in economic and environmental point of view. Mechanization has a crucial role in this venture as it functions as a force multiplier to compensate the human labour shortage for those engaged in food production (Harisudan, 2012). At this point of view a study on analysing the impact of machine transplanting in Cauvery delta districts was taken up. In Tamil Nadu, Thanjavur, Tiruvarur, Nagapattinam, Trichy, Ariyalur and Cuddalore are the Delta districts covered under Cauvery Delta Zone. The impact study on machine transplantation was taken up at Cauvery Delta region of Cuddalore District. This study aims at analyse the Comparative economics in seedling production and Merits and Demerits of machine transplanting in Cavery delta zone.

\section{Objective}

The main objective is to assess the impact of machine transplanting in rice and its socio economic comparison with conventional method of transplanting in Cauvery Delta Region of Cuddalore District, Tamil Nadu.

\section{Materials and Methods}

Impact study of machine transplantation of rice and its socio economic comparison with conventional method in Cauvery Delta region of Cuddalore District was carried out during 2016. The study area includes, Parangipettai, Kattumannarkoil, Melbhuvanagiri, Keerapalayam and Kumaratchi blocks of Cuddalore District in which the Government of Tamil Nadu has implemented the Kuruvai
Package. Based on the number beneficiaries of the program in each districts, proportionate simple random sampling procedure (Gravetter and Forzano, 2011) was followed to select the respondents. During the year 2015, 1006 farmers received Kuruvai package of the Government of Tamil Nadu. In Cuddalore District, 83 farmers received Kuruvai Package. They served as the sample for the study. It has been decided to select 25 per cent of the population as sample, and accordingly the sample size has been fixed as 21 farmers. Beneficiary farmers list has been obtained from the office of Joint District of Agriculture, Cuddalore and by employing simple random sampling procedure, 21 farmers were selected. As the study focuses on the impact of the machine transplantation, we selected four control farmers who have raised Kuruvai crop without Government assistance, for easy comparison. These control farmers were selected considering their rich experience in Kuruvai cultivation and thus the final sample for the study at Cuddalore district was fixed as 25. A well structured interview schedule was used to collect primary data. The questionnaire was pretested and validated. The interview schedule covered the aspects such as farmers' personal particulars, Kuruvai land use pattern, crop cultivation details with special reference to cost factor in both conventional and machine planting methods, merits and demerits of the mechanical transplanting.

\section{Findings and discussion}

\section{Profile of the respondents}

The findings of the beneficiaries with regard to their age distribution are given in Table 1 , which revealed that little more than half of the beneficiaries (52.00 per cent) were in the age range of 30 to 50 and almost about fifty percentage of the beneficiaries (48.00 per cent) were found under the age group of 
above 50. None of the farmers were seen in the young age group. While referring to the educational status of the respondents it is observed that an overwhelming majority of the beneficiaries ( 96.00 per cent) were found literates. Majority of the beneficiaries (44 per cent) were graduates.

The findings are given in Table 2 revealed that about one third of the beneficiaries $(32.00$ $\%$ ) were seen in the range of 11 to 20 years of experience. Around thirty percentage (28.00 per cent) of the beneficiaries had more than 30 years of experience in farming, followed by around one fourth (24.00 per cent) had less than 10 years of experience. Sixteen percentage of the beneficiaries were seen in the experience range of 21 to 30 years. With reference to farm holdings the finding revealed that 40 percentage of the beneficiaries were large farmers followed by medium (32 per cent), small ( 24 per cent) and marginal (4 per cent) farmers.

\section{Major rice varieties grown}

The findings are summarized in Table 3, which shows that ASD 16 is the major rice variety being cultivated in kuruvai season in Cuddalore district and it is being cultivated by more than one third of the beneficiaries (36 per cent). Ponni and ADT 43 are the second major rice varieties being cultivated by an equal percentage of the beneficiaries ( 24 per cent). The other varieties viz., Anjali, Prasanna and CO 51 are being cultivated by a meagre percentage of the beneficiaries.

With regard to the human labour engagement in conventional nursery, it was ten average mandays involving an average labour cost of Rs.2000/- for an acre and in mat nursery the labour engagement was lesser than conventional nursery (i.e. 6 man days with a labour cost of Rs.1200/acre). At the same time the machine power engagement in both conventional and mat nursery management was minimum and equal (i.e. 2 hours of machine power involving Rs.1200/acre). With regard to the seed and seed cost, in conventional method on an average $37 \mathrm{kgs}$ of seed with a total average cost of Rs.1175/acre was incurred, but in mat nursery the average seed quantity was only $18 \mathrm{kgs}$ with an average cost of Rs.543. Moreover an average quantity of $35 \mathrm{kgs}$ of DAP was used in conventional nursery by incurring an average cost of Rs.770/acre and in machine planting mat nursery method no fertilizer was used and hence there was no cost involved.

Again, in the use of plant protection chemicals on an average $90 \mathrm{ml}$ profenophos was used in conventional nursery by incurring an average cost of Rs.100 and in mat nursery method the beneficiaries used only $45 \mathrm{ml}$ of profenophos with an average cost of Rs.55. Further, it has been worked out that the interest on working capital in conventional nursery was Rs.367/- and in mat nursery it was Rs.210/- only. Finally it is learnt that the total average cost of nursery management in conventional method was Rs.5612 and in mat nursery it was Rs.3208/- (i.e. Rs.2404 saving to the tune of 59 percentage in mat nursery method).

\section{Social impact of machine transplanting}

The findings on the merits of machine transplanting are given in Table 5, which showed that cent percentage of the beneficiaries stated that the machine transplanting has contributed to yield increase, reduction in cost of cultivation, more area coverage, reduction in labour drudgery, less efforts in nursery maintenance and reduced seed cost. For transplanting, walking in puddled field alone consumed 72 to $87 \%$ of total energy expense of male workers whereas for female workers it varied from 83 to 89\% (Prabhat Kumar Guru et al., 2018). 
Table.1 Age wise distribution of respondents

\begin{tabular}{|c|c|c|}
\hline S.No & Age (years) & Number of farmers \\
\hline $\mathbf{1 .}$ & $<30$ & 00 \\
\hline $\mathbf{2 .}$ & $30-50$ & $13(52)$ \\
\hline $\mathbf{3 .}$ & $>50$ & $12(48)$ \\
\hline \multicolumn{2}{|c|}{ Total } & $\mathbf{2 5}$ \\
\hline
\end{tabular}

Figures in parentheses indicate percentage to total sample farmers

Table.2 Farming experience of the respondents

\begin{tabular}{|c|c|c|}
\hline S.No & Experience (years) & Number of farmers \\
\hline $\mathbf{1 .}$ & $<10$ & $6(24)$ \\
\hline $\mathbf{2 .}$ & $11-20$ & $8(32)$ \\
\hline $\mathbf{3 .}$ & $21-30$ & $4(16)$ \\
\hline $\mathbf{4}$ & $>30$ & $7(28)$ \\
\hline & Total & 25 \\
\hline
\end{tabular}

Figures in parentheses indicate percentage to total sample farmers

Table.3 Major Rice Varieties grown by the respondents

\begin{tabular}{|c|l|c|}
\hline S.No & \multicolumn{1}{|c|}{ Rice variety } & Number of farmers \\
\hline $\mathbf{1 .}$ & ADT 36 & 0 \\
\hline $\mathbf{2 .}$ & ADT 43 & $6(24)$ \\
\hline $\mathbf{3 .}$ & ADT 45 & 0 \\
\hline $\mathbf{4 .}$ & ADT 37 & 0 \\
\hline $\mathbf{5 .}$ & ASD 16 & $9(36)$ \\
\hline $\mathbf{6 .}$ & CO 51 & $1(4)$ \\
\hline $\mathbf{7 .}$ & Ponni & $6(24)$ \\
\hline $\mathbf{8 .}$ & Anjali & $2(8)$ \\
\hline $\mathbf{9 .}$ & Prasanna & $1(4)$ \\
\hline & Total & $25(100)$ \\
\hline
\end{tabular}

Figures in parentheses indicate percentage to total sample farmers 
Table.4 Comparative economics of rice seedling production per acre

\begin{tabular}{|c|c|c|c|c|c|}
\hline \multirow[t]{2}{*}{ S.No } & \multirow[t]{2}{*}{ Particulars } & \multicolumn{2}{|c|}{ Conventional Nursery } & \multicolumn{2}{|c|}{ Mat Nursery } \\
\hline & & $\begin{array}{l}\text { Physical } \\
\text { Quantity }\end{array}$ & $\begin{array}{l}\text { Cost } \\
\text { (Rs.) }\end{array}$ & $\begin{array}{l}\text { Physical } \\
\text { Quantity }\end{array}$ & $\begin{array}{l}\text { Cost } \\
\text { (Rs.) }\end{array}$ \\
\hline 1. & Human Labour (Man days) & 10 & 2000 & 6 & 1200 \\
\hline 2. & Machine Power (hours) & 2 & 1200 & 2 & 1200 \\
\hline 3. & Seeds (Kgs) & 37 & 1175 & 18 & 543 \\
\hline 4. & $\begin{array}{l}\text { Fertilizer and manures (Kgs)- } \\
\text { DAP }\end{array}$ & 35 & 770 & 0 & 0 \\
\hline 5. & $\begin{array}{l}\text { Plant protection chemicals } \\
\text { (litres / gram)- Profenophos }\end{array}$ & 90 & 100 & 45 & 55 \\
\hline 6. & $\begin{array}{l}\text { Interest on working capital @ } \\
7 \%\end{array}$ & - & 367 & - & 210 \\
\hline \multicolumn{3}{|c|}{ Total cost } & 5612 & & 3208 \\
\hline
\end{tabular}

Table.5 Merits of the mechanical transplanting reported by the farmers

\begin{tabular}{|c|l|c|c|}
\hline $\begin{array}{c}\text { S. } \\
\text { No }\end{array}$ & \multicolumn{1}{|l|}{ Merits of the mechanical transplanting } & Mean score (\%) & Rank \\
\hline $\mathbf{1 .}$ & It is possible to plant young seedlings & 90 & 1 \\
\hline $\mathbf{2 .}$ & Timely planting & 95 & 2 \\
\hline $\mathbf{3 .}$ & Reduce seed cost & 100 & 1 \\
\hline $\mathbf{4 .}$ & Nursery maintenance very less & 100 & 1 \\
\hline $\mathbf{5 .}$ & $\begin{array}{l}\text { Human drudgery reduction } \\
\text { (less workload to laborers) }\end{array}$ & 100 & 1 \\
\hline $\mathbf{6 .}$ & Labour scarcity addressed & 95 & 2 \\
\hline $\mathbf{7 .}$ & More area coverage & 100 & 1 \\
\hline $\mathbf{8 .}$ & Reduce the cost of cultivation & 100 & 1 \\
\hline $\mathbf{9 .}$ & Increase in yield & 100 & 1 \\
\hline
\end{tabular}

Table.6 Demerits of the mechanical transplanting reported by the farmers

\begin{tabular}{|c|l|c|c|}
\hline S. No & Demerits of the mechanical transplanting & Mean score (\%) & Rank \\
\hline $\mathbf{1 .}$ & Skill involved in nursery preparation & 100 & 1 \\
\hline $\mathbf{2 .}$ & Non availability of machine & 38 & 3 \\
\hline $\mathbf{3 .}$ & Too much of seedlings per hill & 33 & 4 \\
\hline $\mathbf{4 .}$ & More cost for land preparation & 95 & 2 \\
\hline $\mathbf{5 .}$ & Gap filling is necessary & 100 & 1 \\
\hline $\mathbf{6 .}$ & $\begin{array}{l}\text { Mobility of the trans planter difficulty due to } \\
\text { smaller fields }\end{array}$ & 95 & 2 \\
\hline $\mathbf{7 .}$ & High cost & 38 & 3 \\
\hline
\end{tabular}


An ergonomic study on human drudgery and musculoskeletal disorders shows that manual rice transplanting, demanding high labor and directly associated with human drudgery (pain in neck, both shoulder, upper back, lower back and thighs) because the labors were compelled to adopt bending and sitting posture during manual uprooting and transplanting (Ojha \& Kwatra, 2012). Positive effect of machine transplanting on yield and economic returns of rice cultivation was also reported by Senthilkumar et al., 2016.

An overwhelming majority of the beneficiaries ( 95 per cent) have reported that the machine transplanting facilitates timely planting and solves the issue of labour scarcity. Similar facts of reduced labour requirement and timely completion of crop establishment operations was reported by Mohammad Shahid et al., 2019.

Table 6, reveals that Cent percentage of the beneficiaries reported that the machine planting requires appropriate technical skills in nursery raising and the local extension officials need to address this issue by organizing special training programme at appropriate time. Similarly all the beneficiaries reported that in machine planting lot of seedling gaps are left out and human labours are required to engage gap filling work.

Majority of the beneficiaries (95 per cent) reported the issues such as higher cost of land preparation and mobility of the machine in the smaller/fragmented fields as the demerits. Further, a similar percentage of the beneficiaries (38 per cent) stated that the transplanters are not available locally and in sufficient numbers and also the higher cost of the machine as the demerits. About one third of the beneficiaries (33 per cent) reported that the machine leaves more seedling/hill which also a perceived demerit.
The focused research study revealed that majority of the farmers with the farming experience of $10-30$ years, cultivating major varieties viz., ASD 16, ADT 43 and Ponni reported the total cost of production in mat nursery method is much less than the conventional method and it saves 59 percentage in cost of production when compared to conventional method. Increased yield, reduced cost of cultivation, more area coverage, labour drudgery reduction, less effort in nursery maintenance, reduced seed cost, efficient labour management and timely planting are the major merits of machine transplanting.

\section{References}

Gravetter, F.J \& Forzano, L.B. 2011. Research methods for the behavioural science. Cengage Learning. p.146.

Harisudan, C., 2011. Partial mechanization of rice cultivation for enhancing productivity and energetics. In Proc. of International symposium on "100 years of Rice science and looking beyond" to be held during $9^{\text {th }}-12^{\text {th }}$ January, 2012 at TNAU, Coimbatore.

Mohammad Shahid, A.K. Nayak, R.Tripathi, Sangita Mohanty, B.B. Panda, S. Saha, Vijayakumar S, S.D.Mohapatra, S.Priyadarsini, P.K. Guru, S. Munda, D.R. Sarangi, Udaya Sekhar Nagothu and H. Pathak. 2019. Machanical Transplanting of rice. Resilience. 3 .

Ojha.P and Kwatra S. 2012 An ergonomic study on humandrudgery and musculoskeletal disorders by rice transplanting. Stud. Home Com. Sci. 6(1): 15-20.

Prabhat Kumar Guru, N.K Chhuneja, A.Dixit, P.Tiwari and Anjani Kumar. 2018. Mechanical transplanting of rice in India : Status, technological gaps and future trust. Oryza. 55(1): 100-106.

Season and Crop Report, 2016-17, 
Department of Economics and mechanization strategies of rice Statistics, Tamil Nadu, p.104.

Senthilkumar. T., S. Radhamani, R. Kavitha and Ravindra Naik. 2016. Studies on Mechanized Rice Transplanting and SRI Method of Rice Cultivation. Journal of Rice Research 9(1): 43-46.

Verma A (2010). Modelling for cultivation in Chhattisgarh, India. Agril. Mech. in Asia, Africa and Latin America 41(1): 20-26.

Yadav, B.K., and B.S. Kherawat (2013). Selective mechanization for enhancing productivity of rice cultivation. $J$. of Agril. Engg. 6(1): 289-290.

\section{How to cite this article:}

Nirmala Devi. M., C. Harisudan and Arunachalam. R. 2020. Impact Study of Machine Transplantation in Rice and its Socio Economic Comparison with Conventional Method in Cauvery Delta Region of Tamil Nadu, India. Int.J.Curr.Microbiol.App.Sci. 9(06): 977-983. doi: https://doi.org/10.20546/ijcmas.2020.906.122 